\title{
Effect of the particle size of spray-dried milk powder on some properties of chocolate
}

\author{
Kieran KEOGH*, Cathriona MURRAY, James KELLY, Brendan O'KeNNEDY \\ Teagasc, Dairy Products Research Centre, Moorepark, Fermoy, Co. Cork, Ireland
}

Received 1 September 2003 - Accepted 18 March 2004

Published online 7 June 2004

\begin{abstract}
Spray-dried milk powders have a median particle size of 30-80 $\mu \mathrm{m}$. Roller-dried powder particles, which are larger (about $150 \mu \mathrm{m}$ ), are preferred for chocolate making. Spray-drying variables were therefore studied to produce larger powder particles for chocolate. The particle size of the spray-dried powders increased with increasing size of the spray nozzle orifice used. The free-fat content, vacuole volume and insolubility index of the powders increased at the above normal air outlet temperatures used to dry the large powder particles. Vacuole volume and moisture contents typical for spray-dried powders were obtainable at air outlet temperatures up to $90^{\circ} \mathrm{C}$. The particle size of the chocolate mix after refining and the Casson yield value of the chocolate after conching reached minimum values using spray-dried powders with median particle size values of 132-162 $\mu \mathrm{m}$. These minimum values in the chocolates were also correlated with higher contents of free-fat and lower vacuole volumes in the powders. The spray-dried powders produced good quality Britishstyle chocolates, where the particle size after refining is conventionally $<26 \mu \mathrm{m}$, but not continental chocolates, where the particle size should be $<20 \mu \mathrm{m}$.
\end{abstract}

\section{Spray-drying / milk powder / particle size / chocolate rheology}

Résumé - Effets de la taille des particules de la poudre de lait sur les propriétés du chocolat. La taille moyenne des particules des poudres de lait séchées par atomisation est, en générale, comprise entre 30 et $80 \mu \mathrm{m}$. En chocolaterie, on préfère l'emploi de poudres de lait séché sur rouleaux (taille des particules de l'ordre de $150 \mu \mathrm{m}$ ). Ainsi la modification des conditions de séchage par atomisation, pour obtenir des particules de taille plus élevée, a été étudiée pour cet usage. La taille des particules des poudres atomisées augmentait avec l'accroissement du diamètre des buses utilisées. La teneur en matière grasse libre, le volume vacuolaire et l'indice d'insoluble des poudres étaient accrus avec l'élévation de la température de l'air de sortie. Le volume vacuolaire ainsi que la teneur en eau recherchés pour l'utilisation en chocolaterie étaient obtenus pour une température d'air de sortie de $90{ }^{\circ} \mathrm{C}$. Les poudres ainsi obtenues, avaient des particules de taille moyenne comprise entre 132 et $162 \mu \mathrm{m}$, une teneur élevée en matière grasse libre et un faible volume vacuolaire. Ces poudres satisfaisaient ainsi aux valeurs minimales requises pour le « mix » chocolat après raffinage et pour la valeur limite d'écoulement selon Casson après conchage. Elles permettaient l'obtention de chocolat de type britannique de bonne qualité (où il est recherché des particules de taille $<26 \mu \mathrm{m}$, après raffinage et conchage), mais elles ne convenaient pas pour l'utilisation en fabrication de chocolats de type européen (où il est recherché des particules de taille $<20 \mu \mathrm{m}$ ).

Poudre de lait / séchage / atomisation / taille de particule / rhéologie du chocolat

\footnotetext{
* Corresponding author: kkeogh@moorepark.teagasc.ie
} 


\section{INTRODUCTION}

Roller-dried milk powder containing $26 \mathrm{~g}$ fat $\cdot 100 \mathrm{~g}^{-1}$ powder is preferentially used in milk chocolate because of its high content of free-fat (>90 g.100 g $\mathrm{g}^{-1}$ fat is solvent extractable), large lamellar-shaped particles (median particle size is about $150 \mu \mathrm{m}$ ) and absence of vacuoles [8]. Increasing free-fat in milk powders reduces the ratio of the dispersed phase to the continuous fat phase in chocolate, thus beneficially reducing the values of the Casson viscosity and yield value of the molten chocolate at the end of conching [12]. Conversely, a smaller particle size in chocolate after refining results in higher rheological parameters in the chocolate at the end of conching [1]. This is because smaller particles have larger surface areas, which adsorb larger amounts of the continuous fat phase. Vacuoles in spray-dried milk powder particles increase the volume to mass ratio. The presence of vacuoles also leads to shattering of the powder particles during refining of the chocolate mix, which results in the formation of small particles or fines and higher rheological values in the subsequent molten chocolate [9].

The production of milk powder by spraydrying is now the norm in the milk powder industry, as the process is more efficient in terms of energy and scale. However, spraydried milk powders containing $26 \mathrm{~g}$ fat $\cdot 100 \mathrm{~g}^{-1}$ powder have $<10 \mathrm{~g}$ free-fat $\cdot 100 \mathrm{~g}^{-1}$ fat, have spherical shaped particles (typically median particle size $30-80 \mu \mathrm{m}$ ) and contain up to $10 \mathrm{~mL}$ vacuole volume $\cdot 100 \mathrm{~g}^{-1}$ powder. These properties make them less suitable for chocolate manufacture [8]. Recent work [12] demonstrated the positive effects of using blends of high-fat milk powder and skim milk powder in chocolate. High-fat ( $56 \mathrm{~g}$ fat $\left.\cdot 100 \mathrm{~g}^{-1}\right)$ milk powders have higher levels of free-fat which, even when blended with skim milk powder to the standard fat content result in a reduced particle size of the chocolate mix after refining. It seems that chocolate mixes containing high fat powder/skim milk powder blends are more easily refined. Significantly, the smaller particle size of the refined mix was associated with a decrease rather than an increase in the Casson viscosity of the molten chocolate at the end of conching, presumably because the increased free-fat outweighed the effects of the smaller particle size of the chocolate mix. Higher fat powders also had lower vacuole volumes due to the foam depressing effects of fat, which resulted in a lower Casson yield value of the molten chocolates. The free-fat content of the milk powders was also increased by ultrafiltration of the milks to increase the protein content relative to lactose, but the increased protein counteracted the effect of increased free-fat on the Casson viscosity. Increasing the viscosity of the milk concentrate increased the particle size of the milk powders, but the associated increase in moisture levels of the powders counteracted the expected decrease in the Casson yield value of the molten chocolates. A small decrease in the Casson viscosity of the molten chocolates $(\sim 0.3$ Pas, $P<0.05)$ was however achieved.

The effect of the particle size of milk powders with similar moisture contents and vacuole volumes on the properties of chocolate should therefore be investigated. It was shown [14] that the median particle size of high-fat powders ( $55 \mathrm{~g}$ fat $\cdot 100 \mathrm{~g}^{-1}$ ) produced with a 2-fluid nozzle/Anhydro pilotscale dryer varied seasonally from 28 to $66 \mu \mathrm{m}$. Using blends of the high-fat and skim milk powders to give a standard pow$\operatorname{der}\left(26 \mathrm{~g}\right.$ fat $\left.\cdot 100 \mathrm{~g}^{-1}\right)$, the Casson viscosity decreased by 1.20 Pas $(P<0.05)$ as the particle size increased at the mean value of the other properties of the high-fat powder [15]. It is still necessary to produce standard spray-dried powders with particles as large as roller-dried powder $(\sim 150 \mu \mathrm{m})$ for evaluation in chocolate. This is the main objective of the current work, but high levels of free-fat and low levels of vacuole volume, typical of roller-dried powders, are not expected. Up to now, the milk powder industry has not provided a spray-dried milk powder with a particle size optimised 
Table I. Characteristics of nozzles.

\begin{tabular}{lccc}
\hline $\begin{array}{l}\text { Size } \\
\text { (cat. no.) }\end{array}$ & $\begin{array}{c}\text { Orifice size } \\
\text { (diameter, mm) }\end{array}$ & $\begin{array}{c}\text { Core size } \\
\text { (cat. no.) }\end{array}$ & $\begin{array}{c}\text { Number of nozzles } \\
\text { used }\end{array}$ \\
\hline 74 & 0.57 & 20 & 3 \\
60 & 1.01 & 20 & 2 \\
56 & 1.19 & 21 & 2 \\
50 & 1.77 & 21 & 1 \\
49 & 1.85 & 27 & 1 \\
48 & 1.93 & 27 & 1 \\
44 & 2.18 & 27 & 1 \\
\hline
\end{tabular}

specifically for the chocolate industry. The reason for this was partly that the production of large particle size powders is outside the norm in standard spray-dried powders, but still achievable.

The composition and processing of chocolate also has major effects on its properties, especially the fat content, the refining conditions (gap width and roller pressure), conching time and tempering conditions. In the current work, the chocolate-making recipe was as before [12] but the refining conditions were slightly altered.

\section{MATERIALS AND METHODS}

\subsection{Milk standardisation}

Whole milk from a local manufacturing plant supplied from mainly Spring-calving herds was used. Storage, pasteurisation, separation and analyses of the milks were as already reported [14] and a short summary is given here. The whole milk was standardised by separating a portion of skim milk, which was used to adjust the milk to give a milk powder composition equivalent to $26 \mathrm{~g}$ fat $\cdot 100 \mathrm{~g}^{-1}$ powder. The standardised milk was then heated at $97.5^{\circ} \mathrm{C} \times 2 \mathrm{~min}$ in the pasteuriser section of an evaporator to increase the heat stability of the concentrated milk and subsequently cooled to $45^{\circ} \mathrm{C}$.

\subsection{Milk concentration and drying}

The heat-treated milk was then concentrated to $39-55 \mathrm{~g}$ solids $\cdot 100 \mathrm{~g}^{-1}$ in a pilot-scale
Niro 3-effect falling film evaporator with a water evaporation capacity of $800 \mathrm{~kg} \cdot \mathrm{h}^{-1}$. The concentrate was pumped by positive displacement pump from the evaporator through a scraped-surface heat exchanger, where the temperature of the concentrate was raised to $65^{\circ} \mathrm{C}$. From here, the concentrate was delivered by means of a high-pressure pump to the atomiser of a Tall-Form dryer, model TDF-20 (Niro A/S, Copenhagen, Denmark). The pilot scale dryer had a nominal water evaporation capacity of 70$100 \mathrm{~kg} \cdot \mathrm{h}^{-1}$. The concentrate was spray atomised using nozzles of various orifice size (Tab. I), as supplied by Spraying Systems Ltd., Farnham, UK. Nozzle size numbers 50 to 44 were larger than conventionally used, in order to obtain large spray-dried milk powder particles in the range 100 $200 \mu \mathrm{m}$ for the manufacture of chocolate. The temperature of the inlet air applied to the Tall-Form dryer of $180^{\circ} \mathrm{C}$ is typical but the temperatures of the outlet air of 80 $115^{\circ} \mathrm{C}$ are higher than the conventional range of $68-75^{\circ} \mathrm{C}$ for this dryer. The powders were stored in sealed bags at a constant temperature of $15^{\circ} \mathrm{C}$.

\subsection{Compositional analysis of milk concentrates and powders}

The total solids of the milk concentrates were determined by microwave heating, using a CEM LabWave 9000 (CEM Corp., Matthews, NC, USA). The moisture content of the milk powders was determined by 
the oven drying method [2]. The free-fat content was determined by the Niro method [3] using $\mathrm{CCl}_{4}$ as solvent with constant shaking over $15 \mathrm{~min}$. All tests were carried out in duplicate and the mean calculated.

\subsection{Viscosity of concentrates}

A strain-controlled Bohlin VOR rheometer (Bohlin, Cirencester, UK) with concentric cylinder geometry was used. Samples of milk concentrate were taken from the evaporator and $13.25 \mathrm{~g}$ was weighed into a C25 cup. The samples were subjected to a pre-shear at $461 \mathrm{~s}^{-1}$ for $300 \mathrm{~s}$ at $45^{\circ} \mathrm{C}$, followed by an up and down shear rate sweep from 1.16-461 s-1 and the mean values of each sweep taken. The concentrate viscosity profiles obeyed the power law model most closely ( $r>0.998)$, that is:

$$
\sigma=k \dot{\gamma}^{n}
$$

where $\sigma$ is the shear stress $(\mathrm{Pa}), \dot{\gamma}$ is the rate of shear $\left(\mathrm{s}^{-1}\right)$, the exponent $n$ is the power law factor and $k$ is the consistency index $\left(\operatorname{Pas}^{\mathrm{n}-1}\right)$ or the viscosity $\left(\mathrm{Pas}^{\mathrm{n}}\right)$ at $\dot{\gamma}=1 \mathrm{~s}^{-1}$.

\subsection{Particle size of milk powders}

The size of the particles in the milk powders was measured using a Malvern Mastersizer X (Malvern Instruments, Malvern, UK) fitted with an MSX15 small volume sample presentation unit. The instrument uses an approximation of the Mie-scattering theory to determine particle size, which utilises the refractive index of the dispersed phase and its absorption. A relative refractive index of 1.095 and an absorption value of 0.1 were used in the calculations. A $2 \mathrm{~mW}$ He-Ne laser beam $(633 \mathrm{~nm})$ and a $300 \mathrm{RF}$ lens (size range 0.05 to $879 \mu \mathrm{m}$ ) were used for the measurements. The powders were suspended in propan-2-ol and sonicated (Sonicator, Hielscherr, Germany, model UP 200H) for $2 \mathrm{~min}$ before each determination. The results are expressed as the volume weighted median diameter $\mathrm{D}(\mathrm{v}, 0.5)$.

\subsection{Vacuole volume}

The particle density $\left(\mathrm{g} \cdot \mathrm{mL}^{-1}\right)$ was first calculated by measuring the air-free volume of a known weight of powder using a pycnometer (AccuPyc 1330, Micromeritics, Norcross, GA, USA). The pycnometer determined the density of milk powder by measuring the pressure change of helium in a calibrated volume. The vacuole volume was calculated from the difference between the solids and particle densities [4].

\subsection{Powder insolubility index}

The powder insolubility index was measured after reconstituting $13.0 \mathrm{~g}$ powder in $100 \mathrm{~mL}$ water at $24^{\circ} \mathrm{C}$ [10].

\subsection{Statistical analysis}

The properties of the milk concentrates, powders and chocolates were correlated using simple linear regression with intercept using the statistical functions in Microsoft Excel software. The significance levels were based on the analysis of variance using a 2-tailed Student's t-test [5].

\subsection{Chocolate ingredients}

The milk chocolate recipe had a $25 \mathrm{~g} \cdot 100 \mathrm{~g}^{-1}$ incorporation rate of milk powder, mean total fat content of $30.9 \mathrm{~g} \cdot 100 \mathrm{~g}^{-1}$ and moisture content of $1.2 \mathrm{~g} \cdot 100 \mathrm{~g}^{-1}$. The following ingredients were used in the manufacture of milk chocolates as previously described [12]:

- Cocoa butter (Cadbury Ireland Ltd, Dublin);

- Cocoa liquor (Nestlé Rowntree, Mallow, Co. Cork);

- Sucrose (Irish Sugar Company, Mallow, Co. Cork);

- Milk powders (prepared as described above);

- Lecithin (Topcithin 300, Lucas Meyer, Hamburg, Germany).

\subsection{Chocolate process}

The process remained unchanged from before [12], except the gap widths were 
reduced and pressure increased between the rollers of the three-roll refiner used (Bühler, New Barnet, Herts., UK) as follows: to $280 \mu \mathrm{m}$ and 3.0 MPa between each pair of rollers in the first pass through the refiner and to $70 \mu \mathrm{m}$ and $3.0 \mathrm{MPa}$ in the second pass. These settings gave a particle size of $25 \mu \mathrm{m}$ in the chocolate after refining when a spray-dried milk powder containing $26 \mathrm{~g}$ fat $100 \mathrm{~g}^{-1}$ with a median particle size of $132 \mu \mathrm{m}$ was used. For the roller-dried powders, a wider gap width of $140 \mu \mathrm{m}$ at the same pressure was used in the second pass to give a particle size after refining of $<20 \mu \mathrm{m}$. The refined mix $(7 \mathrm{~kg})$ was then conched in the Lipp conch (Lipp Mischtechnik, Mannheim, Germany) for $7 \mathrm{~h}$ at $60{ }^{\circ} \mathrm{C}$. Lecithin $\left(0.2 \mathrm{~g} \cdot 100 \mathrm{~g}^{-1}\right)$ and the remaining cocoa butter were added after $5 \mathrm{~h}$ of conching. A sample of molten chocolate was taken for rheological assessment at the end of the conching stage and the remaining chocolate was stored in an incubator overnight at $50{ }^{\circ} \mathrm{C}$.

On the following day, two $2 \mathrm{~kg}$ portions of the chocolate were tempered as before. The moulded chocolate was placed in a temperature-controlled room at $15{ }^{\circ} \mathrm{C}$ for 30 min before de-moulding and the finished bars were wrapped in aluminium foil and stored at $15{ }^{\circ} \mathrm{C}$ until analysed.

\subsection{Rheological properties of milk chocolate}

Samples of the molten chocolate were taken at the end of conching for rheological evaluation in a strain-controlled Bohlin VOR rheometer (Bohlin, Cirencester, UK) with concentric cylinder geometry. All measurements were made at $40{ }^{\circ} \mathrm{C}$. Samples were pre-sheared for $2.5 \mathrm{~min}$ at $18.5 \mathrm{~s}^{-1}$ followed by a shear rate sweep from 60 to $1 \mathrm{~s}^{-1}$ in $3.5 \mathrm{~min}$. The data was then used to calculate the Casson viscosity $\left(\eta_{\mathrm{CV}}\right)$ and Casson yield value $\left(\sigma_{\mathrm{CA}}\right)[13]$ using the following equation:

$$
\sqrt{\sigma}=\sqrt{\sigma_{\mathrm{CA}}}+\sqrt{\eta_{\mathrm{CV}}} \sqrt{\dot{\gamma}}
$$

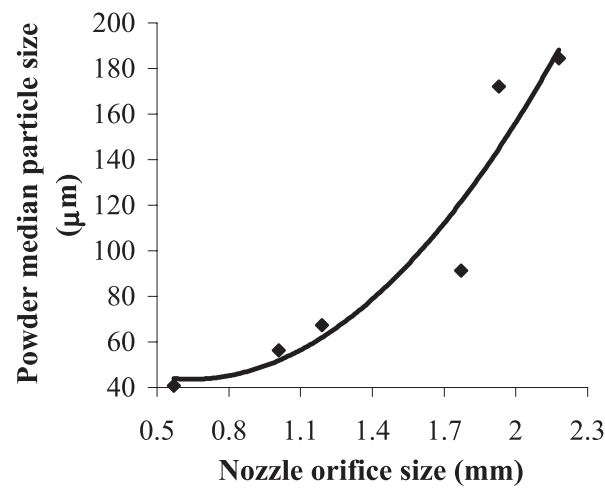

Figure 1. Effect of nozzle orifice size on powder median particle size.

where $\sigma$ is the shear stress $(\mathrm{Pa}), \sigma_{\mathrm{CA}}$ is the Casson yield value $(\mathrm{Pa}), \eta_{\mathrm{CV}}$ is the Casson viscosity (Pas) and $\dot{\gamma}$ is the shear rate $\left(\mathrm{s}^{-1}\right)$.

\section{RESULTS AND DISCUSSION}

\subsection{Effect of nozzle orifice size on milk powder particle size}

Powders containing $26 \mathrm{~g}$ fat $100 \mathrm{~g}^{-1}$ powder (nominal) were first produced with 6 nozzles varying in size as outlined in Table I. Data from milk concentrates with 45.9-47.3 g solids $100 \mathrm{~g}^{-1}$ and dryer air outlet temperatures of 74 or $81{ }^{\circ} \mathrm{C}$ were used (Tab. II). Figure 1 shows that the median particle size $[\mathrm{D}(\mathrm{v}, 0.5)]$ of the powders increased curvilinearly from 41 to $185 \mu \mathrm{m}(r=0.953, n=6, P<0.01)$ as the nozzle orifice size increased. The model indicated that nozzle sizes 50, 48 and 44 $(1.77-2.18 \mathrm{~mm})$ produced powder particles in the size range of interest for chocolate $(130-185 \mu \mathrm{m})$. It has already been established [11] that milk powder particle size increases with the viscosity of the milk concentrate used.

\subsection{Effect of air outlet temperature on some milk powder properties}

Powders were then produced using air outlet temperatures of $74-115^{\circ} \mathrm{C}$ (Tab. II). 
Table II. Properties of concentrates and powders.

\begin{tabular}{|c|c|c|c|c|c|c|c|c|}
\hline \multirow{2}{*}{\multicolumn{2}{|c|}{$\begin{array}{l}\text { Nozzle Air outlet } \\
\text { diameter temperature }\end{array}$}} & \multicolumn{2}{|c|}{ Milk concentrate } & \multicolumn{5}{|c|}{ Milk powder } \\
\hline & & \multirow{2}{*}{$\begin{array}{l}\text { Total solids } \\
\left(\mathrm{g} \cdot 100 \mathrm{~g}^{-1}\right)\end{array}$} & \multirow{2}{*}{$\begin{array}{l}\text { Viscosity } \\
(\mathrm{mPas})^{\mathrm{n}-1}\end{array}$} & \multirow{2}{*}{$\begin{array}{l}\text { Moisture } \\
\left(\mathrm{g} \cdot 100 \mathrm{~g}^{-1}\right)\end{array}$} & \multirow{2}{*}{$\begin{array}{l}\text { Free fat } \\
\left.\cdot 100 \mathrm{~g}^{-1} \mathrm{fat}\right)\end{array}$} & \multirow{2}{*}{$\begin{array}{l}\text { Particle size } \\
{[\mathrm{D}(\mathrm{v}, 0.5) \mu \mathrm{m}]}\end{array}$} & \multirow{2}{*}{$\begin{array}{l}\text { Vac. volume } \\
\left(\mathrm{mL} \cdot 100 \mathrm{~g}^{-1}\right)\end{array}$} & \multirow{2}{*}{$\begin{array}{l}\text { Insolubility } \\
\text { index } \\
\left(\mathrm{mL} \cdot 50 \mathrm{~mL}^{-1}\right)\end{array}$} \\
\hline$(\mathrm{mm})$ & $\left({ }^{\circ} \mathrm{C}\right)$ & & & & & & & \\
\hline \multicolumn{9}{|c|}{ Figure $1($ no. of powders $=6)$} \\
\hline 0.57 & 74 & 45.9 & 153 & 2.4 & 12.9 & 40.8 & 6.00 & 0.10 \\
\hline 1.01 & 74 & 45.9 & 153 & 2.9 & 6.3 & 56.4 & 5.50 & 0.10 \\
\hline 1.19 & 74 & 45.9 & 153 & 3.5 & 7.3 & 67.5 & 4.40 & 0.10 \\
\hline 1.77 & 74 & 47.0 & ND & 3.9 & 7.1 & 91.2 & 5.80 & 0.40 \\
\hline 1.93 & 81 & 47.0 & 536 & 4.7 & 2.4 & 172.1 & 6.50 & 0.10 \\
\hline 2.18 & 81 & 47.3 & 303 & 5.1 & 3.0 & 184.6 & 7.90 & 1.10 \\
\hline \multicolumn{9}{|c|}{ Figures $2 \mathrm{a}, 2 \mathrm{~b}, 2 \mathrm{c}, 2 \mathrm{~d}($ no. of powders $=9$ ) } \\
\hline 1.77 & 74 & 47.0 & ND & 3.9 & 7.1 & 91.2 & 5.75 & 0.40 \\
\hline 1.77 & 81 & 47.0 & ND & 2.3 & 4.2 & 64.5 & 7.88 & 2.00 \\
\hline 2.18 & 81 & 52.3 & 303 & 5.1 & 3.0 & 199.6 & 7.89 & 1.10 \\
\hline 1.77 & 91 & 48.4 & 501 & 2.1 & 20.3 & 75.4 & 10.30 & 2.50 \\
\hline 2.18 & 91 & 52.3 & 303 & 4.1 & 4.6 & 203.3 & 10.78 & 3.00 \\
\hline 1.77 & 100 & 48.4 & 501 & 1.7 & 11.9 & 78.5 & 15.84 & 5.50 \\
\hline 2.18 & 100 & 52.3 & 303 & 3.5 & 6.3 & 203.9 & 15.05 & 5.50 \\
\hline 1.77 & 115 & 48.4 & 501 & 1.2 & 19.9 & 96.6 & 28.12 & 6.00 \\
\hline 2.18 & 115 & 52.3 & 303 & 3.0 & 10.2 & 218.2 & 25.90 & 7.00 \\
\hline
\end{tabular}

In a first series, nozzle size $50(1.77 \mathrm{~mm})$ and milk concentrates containing 47.0 or $48.4 \mathrm{~g}$ solids $100 \mathrm{~g}^{-1}$ were used. A second series was also produced using nozzle size $44(2.18 \mathrm{~mm})$ and a milk concentrate containing $52.3 \mathrm{~g}$ solids $100 \mathrm{~g}^{-1}$. Figure $2 \mathrm{a}$ shows the effects of air outlet temperature on vacuole volume, where the modeled data were coincidental for both nozzles. The vacuole volume increased curvilinearly with air outlet temperature $(r=0.9964, n=$ $9, P<0.001)$, reaching $10.2 \mathrm{~mL} \cdot 100 \mathrm{~g}^{-1}$ powder at air outlet temperature $91^{\circ} \mathrm{C}$. Figure $2 b$ shows the effects of air outlet temperature on free-fat, where the data were nozzle-dependant. The free-fat increased linearly with air outlet temperature for nozzle size $50(1.77 \mathrm{~mm})(r=0.900, n=5$, $P<0.05)$ and for nozzle size $44(2.18 \mathrm{~mm})$
( $r=0.993, n=4, P<0.01)$. The free-fat levels were higher for the smaller nozzle size 50 , because of the smaller powder particle size. The model indicates that free-fat levels of 11 and $5 \mathrm{~g} \cdot 100 \mathrm{~g}^{-1}$ fat were obtained at outlet temperature $91{ }^{\circ} \mathrm{C}$ using nozzles 50 and 44 , respectively. It is known that free-fat increases with air outlet temperature between 70 and $105{ }^{\circ} \mathrm{C}$ [6] and decreases with concentrate total solids [7] using a rotary atomiser.

Figure $2 \mathrm{c}$ shows the effects of air outlet temperature on powder moisture, where the data were nozzle-dependant. The moisture content of the powders decreased curvilinearly with air outlet temperature for nozzle size $50(1.77 \mathrm{~mm})(r=0.963, n=5, P<$ $0.01)$ and for nozzle size $44(2.18 \mathrm{~mm})(r=$ $0.9999, n=4, P<0.001)$. As expected, 


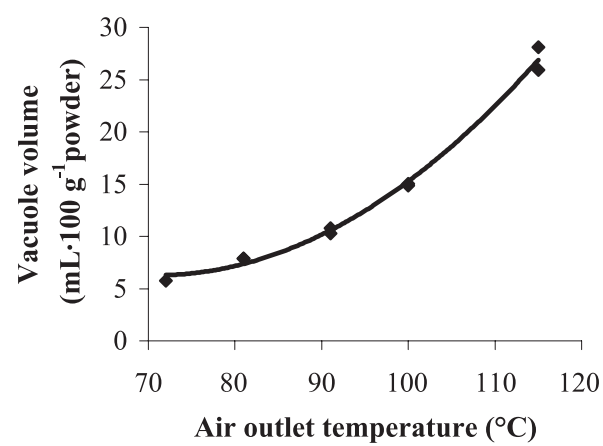

Figure 2a. Effect of air outlet temperature on vacuole volume of powder.

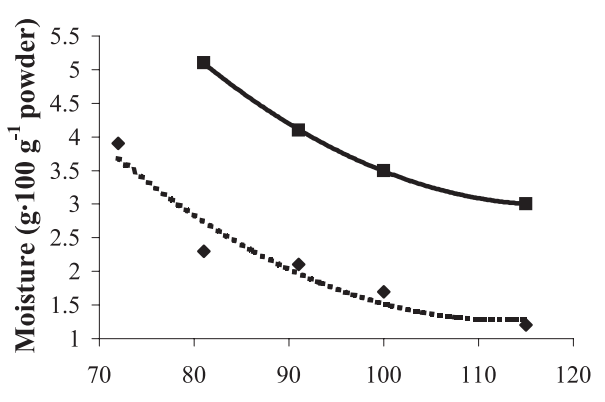

Air outlet temperature $\left({ }^{\circ} \mathrm{C}\right)$

Figure 2c. Effect of air outlet temperature on moisture of powder using spray-dryer nozzle size $1.85 \mathrm{~mm}(-----)$ and nozzle size $2.17 \mathrm{~mm}$ (-口-).

the moisture levels were higher when the larger nozzle size was used but decreased with air outlet temperature with both nozzles [6]. The model indicates that moisture levels of $<3.0 \mathrm{~g} \cdot 100 \mathrm{~g}^{-1}$ powder are obtained at outlet temperatures above $76{ }^{\circ} \mathrm{C}$ and $<2.0 \mathrm{~g} \cdot 100 \mathrm{~g}^{-1}$ at outlet temperatures above $87^{\circ} \mathrm{C}$ using nozzle size 50 .

Figure $2 \mathrm{~d}$ shows the effects of air outlet temperature on the insolubility index, where the modeled data were coincidental for both nozzles. The insolubility index of the powders increased linearly with air out-

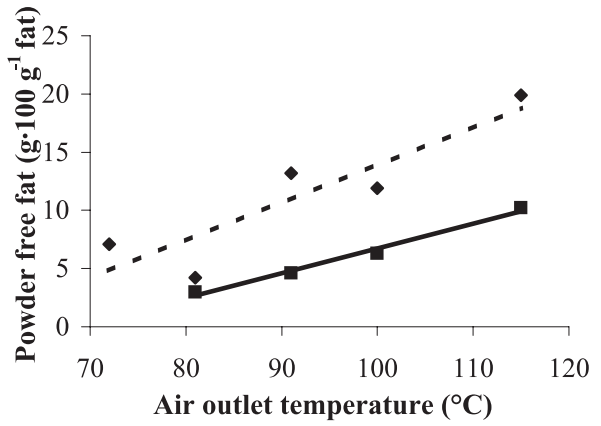

Figure 2b. Effect of air outlet temperature on powder free fat using spray-dryer nozzle size $1.85 \mathrm{~mm}(-----)$ and nozzle size $2.17 \mathrm{~mm}$ (一- -).

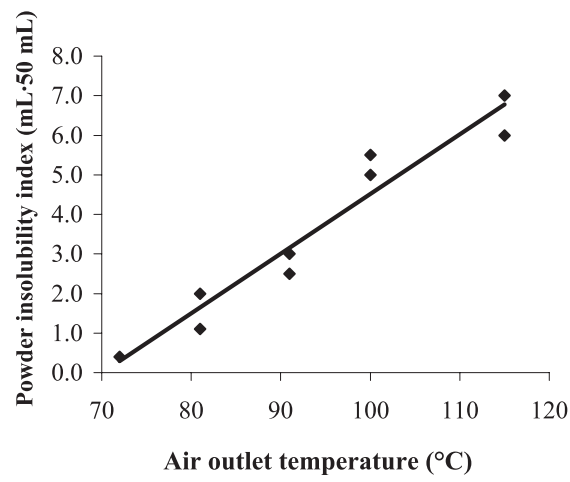

Figure 2d. Effect of air outlet temperature on powder insolubility index. let temperature $(r=0.968, n=9, P<0.001)$. The model indicates that an insolubility index of $3.2 \mathrm{~mL} \cdot 50 \mathrm{~mL}^{-1}$ reconstituted powder was obtained at an air outlet temperature of $91^{\circ} \mathrm{C}$ using either nozzle size.

\subsection{Effect of milk powder particle size on some chocolate properties}

A series of powders ranging in median particle size from 76.8 to $196.2 \mu \mathrm{m}$ was used for making chocolates (Tab. III). Differences in the powder particle size were 
Table III. Properties of milk powders and chocolates.

\begin{tabular}{|c|c|c|c|c|c|c|c|c|}
\hline \multirow{2}{*}{$\begin{array}{l}\text { Nozzle } \\
\text { diameter } \\
(\mathrm{mm})\end{array}$} & \multirow{2}{*}{$\begin{array}{c}\text { Milk } \\
\text { concentrate } \\
\text { total solids } \\
\left(\mathrm{g} \cdot 100 \mathrm{~g}^{-1}\right)\end{array}$} & \multicolumn{4}{|c|}{ Powder } & \multicolumn{3}{|c|}{ Chocolate } \\
\hline & & $\begin{array}{l}\text { Moisture } \\
\left(\mathrm{g} \cdot 100 \mathrm{~g}^{-1}\right)\end{array}$ & $\begin{array}{l}\text { Free fat } \\
100 \mathrm{~g}^{-1} \text { fat }\end{array}$ & $\begin{array}{l}\text { Particle size } \\
{[\mathrm{D}(\mathrm{v}, 0.5) \mu \mathrm{m}}\end{array}$ & $\begin{array}{l}\text { Vac. volume } \\
\left(\mathrm{mL} \cdot 100 \mathrm{~g}^{-1}\right)\end{array}$ & $\begin{array}{l}\text { Particle size } \\
\text { after refining } \\
\qquad(\mu \mathrm{m})\end{array}$ & $\begin{array}{l}\text { Viscosity } \\
\left(\mathrm{Pas}^{\mathrm{n}-1}\right)\end{array}$ & $\begin{array}{c}\text { Yield } \\
\text { value } \\
(\mathrm{Pa})\end{array}$ \\
\hline \multicolumn{9}{|c|}{ Pilot-scale spray-dried } \\
\hline 1.77 & 47.0 & 2.1 & 6.1 & 76.8 & 12.2 & 31 & 1.70 & 25.2 \\
\hline 1.85 & 41.0 & 3.1 & 12.8 & 109.5 & 7.6 & 29 & 1.70 & 20.9 \\
\hline 1.77 & 39.2 & 3.8 & 14.1 & 132.0 & 7.8 & 25 & 1.72 & 20.5 \\
\hline 1.85 & 47.6 & 3.8 & 16.4 & 143.5 & 7.7 & 24 & 1.63 & 19.3 \\
\hline 1.85 & 47.6 & 3.8 & 16.4 & 143.5 & 7.7 & 24 & 1.54 & 18.8 \\
\hline 1.93 & 41.1 & 4.5 & 9.6 & 161.8 & 7.5 & 25 & 1.75 & 22.5 \\
\hline 1.85 & 51.1 & 3.7 & 6.6 & 168.1 & 11.0 & 27 & 1.66 & 23.0 \\
\hline 1.93 & 53.6 & 3.8 & 5.0 & 196.2 & 10.7 & 29 & 1.63 & 21.6 \\
\hline \multicolumn{9}{|c|}{ Commercial roller-dried } \\
\hline NA & NA & 2.8 & 74.6 & 152.9 & 0.0 & 18 & 1.53 & 22.8 \\
\hline NA & NA & 2.9 & 84.2 & 166.3 & 0.0 & 17 & 1.65 & 23.8 \\
\hline
\end{tabular}

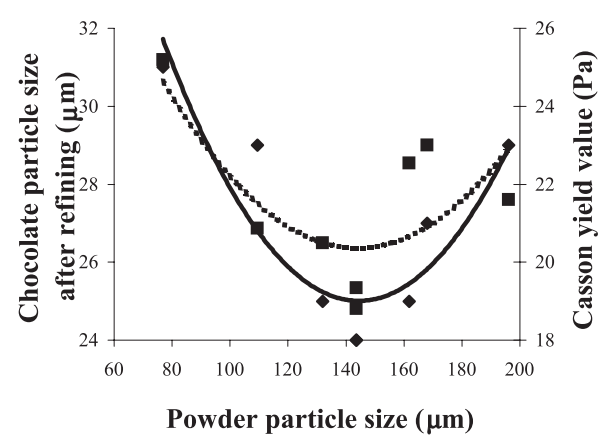

Figure 3. Effect of powder particle size on chocolate particle size after refining (- and on Casson yield value after conching (--- $\mathbf{- - -})$.

achieved using nozzle sizes 50, 49 and 48 and milk concentrates varying in total solids from 39.2 to $54.6 \mathrm{~g} \cdot 100 \mathrm{~g}^{-1}$. An air outlet temperature of $91{ }^{\circ} \mathrm{C}$ was used in order to produce powders with vacuole volume and moisture values as close as possible. Nevertheless, values varied slightly because of the effects of nozzle size and concentrate total solids, as shown in Table III. Figure 3 shows the effect of the powder particle size on the particle size after refining the chocolate mix and on the yield value of the molten chocolates after conching. The particle size after refining reached minimum values of $24-25 \mu \mathrm{m}$ using powders with median particle size values of $132,143,143$ and $162 \mu \mathrm{m}(r=0.904, n=8, P<0.01)$. This is commercially important, as grittiness is detectable in chocolates with particle size values $>26 \mu \mathrm{m}$. This is the standard particle size in British and some US chocolates, though continental European and some US chocolates have a lower particle size of $<20 \mu \mathrm{m}$. A particle size after refining of $<24 \mu \mathrm{m}$ could not be achieved using these spray-dried powders, as the refining conditions used were maximum. By contrast, two commercial roller-dried powders gave chocolates with lower particle sizes after refining of 17 and $18 \mu \mathrm{m}$, but with viscosity and yield values similar to chocolates made 
with spray-dried powders (Tab. III) using our intermediate refining conditions. The particle size after refining was also inversely related to the free-fat content ( $r=$ $-0.737, n=8, P<0.01)$, moisture content $(r=-0.766, n=8, P<0.01)$ and directly to the vacuole volume of these spray-dried milk powders $(r=0.741, n=8, P<0.01)$. This confirms [12] that milk powders with higher free-fat contents produce chocolates with smaller particle size after refining. There was no evidence from the particle size distribution of an increase in fines due to fracturing of the larger powder particles. For the first time, the results suggest that as the moisture content of the milk powders increased, the chocolate mix was more easily refined, possibly due to increasing softness of the powder particles. The Casson viscosity was not affected by any of the variables. However, the Casson yield value reached a minimum value of $19 \mathrm{~Pa}$ using a powder with median particle size $143 \mu \mathrm{m}$ $(r=0.737, n=8, P<0.05)$. The reason for the increase in Casson yield value above a milk powder particle size of $143 \mu \mathrm{m}$ could be due to the lower free-fat $(P<0.01)$ and higher vacuole volume of these powders $(P<0.05$, Tab. III $)$.

\section{CONCLUSIONS}

The median particle size of spray-dried milk powders containing $26 \mathrm{~g}$ fat $\cdot 100 \mathrm{~g}^{-1}$ powder can readily be increased up to $200 \mu \mathrm{m}$ by increasing the nozzle size of the concentrate used for drying. The air outlet temperature must then be increased to about $90{ }^{\circ} \mathrm{C}$ using nozzle size $50(1.77 \mathrm{~mm})$ to reduce the moisture contents of the powder to $2.0 \%$. Under these conditions, the vacuole volume $\left(10 \mathrm{~mL} \cdot 100 \mathrm{~g}^{-1}\right.$ powder $)$ and free-fat content $\left(11 \mathrm{~g} \cdot 100 \mathrm{~g}^{-1}\right.$ fat) of the powders does not match those of rollerdried powders. However, the insolubility index increased to $3.2 \mathrm{~mL} \cdot 50 \mathrm{~mL}^{-1}$ reconstituted powder, making the spray-dried powder more like roller-dried powder. The particle size of the chocolate mix after refin- ing and the Casson yield value of the chocolate after conching reached minimum values using a powder with median particle size $143 \mu \mathrm{m}$. This was also associated with the higher free-fat content and lower vacuole volume of these powders.

Acknowledgments: This project was part-funded by the Food Institution Research Measure (FIRM) under the National Development Plan (NDP). The technical assistance of R. Kennedy and $\mathrm{J}$. O'Keeffe is greatly appreciated.

\section{REFERENCES}

[1] Aguilar C.A., Ziegler G.R., Viscosity of molten milk chocolate with lactose from spraydried whole-milk powders, J. Food Sci. 60 (1995) 120-124.

[2] A/S Niro Atomizer. Determination of moisture, in: Haugaard Sorensen I., Krag J., Pisecky J., Westergaard V. (Eds.), Analytical methods for dry milk products, 4 th edn., De Forenede Trykkerier A/S, Copenhagen, Denmark, 1978, pp. 10-11.

[3] A/S Niro Atomizer. Determination of free-fat on the surface of milk powder particles, in: Haugaard Sorensen I., Krag J., Pisecky J., Westergaard V. (Eds.), Analytical methods for dry milk products, 4 th edn., De Forenede Trykkerier A/S, Copenhagen, Denmark, 1978, p. 46.

[4] A/S Niro Atomizer. Determination of particle density, contents of occluded air and interstitial air, in: Haugaard Sorensen I., Krag J., Pisecky J., Westergaard V. (Eds.), Analytical methods for dry milk products, 4th edn., De Forenede Trykkerier A/S, Copenhagen, Denmark, 1978, pp. 48-51.

[5] Box G.E.P., Hunter W.G., Hunter J.S., Significance tests and confidence intervals for means, variances, proportions, and frequencies, in: Box G.E.P. (Ed.), Statistics for experimenters: An introduction to design, data analysis, and model building, J. Wiley \& Sons, New York, USA, 1998, pp. 107-123.

[6] De Vilder J., Martens R., Naudts M., Influence of process variables on some whole milk powder characteristics, Milchwissenschaft 31 (1976) 396-401.

[7] De Vilder J., Martens R., Naudts M., The influence of the dry matter content, the homogenization and the heating of concentrate on physical characteristics of whole milk powder, Milchwissenschaft 34 (1979) 78-84. 
[8] Dewettinck K., De Moor H., Huyghebaert A., The free-fat content of dried milk products and flow properties of milk chocolate, Milchwissenschaft 51 (1996) 25-28.

[9] Dodson A.G., Lewis D.F., Holgate J.H., Richards S.P., Research Report 495, BFMIRA, Leatherhead, Surrey, UK, 1984.

[10] I.D.F., Determination of insolubility index. Standard 129A, Int. Dairy Fed., Brussels, Belgium, 1988.

[11] Keogh M.K., Murray C.A., O’Kennedy B.T., Effects of ultrafiltration of whole milk on some properties of spray-dried milk powders, Int. Dairy J. 13 (2003) 995-1002.

[12] Keogh M.K., Murray C.A., O’Kennedy B.T., Effects of selected properties of ultrafiltered spray-dried milk powders on some properties of chocolate, Int. Dairy J. 13 (2003) 719-726.

[13] OICC (Office International du Cacao et du Chocolat), Analytical Method: viscosity of chocolate - Determination of Casson Yield Value and Casson plastic viscosity, Int. Choc. Rev. 28 (1973) 223.

[14] Twomey M., Keogh M.K., O’Kennedy B.T., Auty M., Mulvihill D.M., Effect of milk composition on selected properties of spray-dried high-fat and skim-milk powders, Irish $\mathrm{J}$. Agric. Food Res. 39 (2000) 79-94.

[15] Twomey M., Keogh M.K., O’Kennedy B.T., Mulvihill D.M., Seasonal effects of some milk powder characteristics on the rheology of milk chocolate, Irish J. Agric. Food Res. 41 (2002) 105-116. 